11. VIhrov, K. (2002). Vprovadzhennya uroku fizichnoyi kulturi $\mathrm{z}$ elementami futbolu $\mathrm{v}$ shkolah Ukrayini. Fizichne vihovannya v shkoli, 1, 2-3.

12. Danchuk, P. (2004). Futbol yak zasib pidvischennya obsyagu ruhlivoyi aktivnosti i fizichnoyi pidgotovlenosti hloptsiv 12-14 rokiv, yaki prozhivayut $\mathrm{v}$ zonI pIdvischenoyi radIatsiyi. MaterIali naukovoyi konferentsiyi, prisvyachenoyi 110-richchu ukrayinskomu futbolu «Futbol v Ukrayini - vitoki, traditsiyi, perspektivi». Lviv-Kiyiv, 251.

13. Galyuza, S. S. (2012). Teoretiko-metodichnI osoblivostI provedennya zanyat futbolom zi studentkami universitetiv. Pedagogika, psihologiya ta mediko-biologichni problemi fizichnogo vihovannya i sportu, 9, 78.

14. Maksimenko, I. G. (1998). Kontrol za urovnem razvitiya byistrotyi i skorostno-silovyih kachestv u futbolistov razlichnoy kvalifikatsii. Pedagogika, psihologIya ta medikobiologichni problemi fizichnogo vihovannya i sportu, 3, 23-24.

15. Maksimenko, I. G. (2007). Mini-futbol: doslidzhennya pokaznikiv strukturi fizichnoyi pidgotovlenosti 11-14-richnih gravtsiv. Pedagogika, psihologiya ta medikobiologichni problemi fizichnogo vihovannya i sportu, 8, 85-88. 16. Calvin, Y. (2007). Entraineur de football: la technique, corriger pour progresser. Paris : Editions Actio, 194.

Рекомендовано до публікації д-р педаг. наук Васьков Ю. В. Дата надходження рукопису 19.10.2014.

Бойченко Артем Васильович, здобувач, викладач фізичного виховання, кафедра фізичного виховання, Комунальний заклад «Харківська гуманітарно-педагогічна академія» Харківської обласної ради, пров. Ш. Руставелі, 7, м. Харків, Україна, 61001

E-mail: alesik1974@mail.ru

УДК 37.015.3(075.8)

DOI: 10.15587/2313-8416.2014.28405

\title{
ДИФЕРЕНЦІЙОВАНИЙ ПІДХІД ДО ПІДГОТОВКИ МАЙБУТНІХ ФАХІВЦІВ 3 ВАЛЕОЛОГІЧНОЇ ДІЯЛЬНОСТІ В ДОШКІЛЬНИХ УСТАНОВАХ
}

\author{
(C) Т. М. Семанишин, Г. В. Презлята, С. Л. Попель
}

\begin{abstract}
Мета статті - обтрунтувати і розкрити характеристики всіх складових компонентів, включених в авторську теоретичну модель диференційованого підходу з підготовки майбутніх фахівців по фізичній культурі і валеологічному вихованню дошкільнят на основі методу моделювання. Визначено основні складові валеологічної освіти і методи моделювання валеологічної діяльності в дошкільних закладах освіти.

Ключові слова: валеологічна діяльність, дошкільнята, інструктор з фізичного виховання, дошкільні заклади освіти.
\end{abstract}

The purpose of the article is grounding and exposing of descriptions of all components included in the author's theoretical model of the differentiated approach to training of future specialists on physical education and valeology teaching of preschoolers on the basis of modelling method. The basic components of valeology education and valeology activity modelling methods in preschool establishments are determined.

Keywords: valeology activity, preschoolers, physical training instructor, preschool educational establishment.

1. Вступ

Сьогодні, серед багатьох проблем, які вирішуються психолого-педагогічною наукою в дошкільних установах (ДУ) є проблема проектування діяльності освітніх інфраструктур та розробки нових підходів до формування i розвитку здоров'язберігаючих технологій у процесі фізичного виховання дітей дошкільного віку [1, 2]. Тому виникає очевидна необхідність обгрунтування диференційованого підходу, при якому дошкільнята, без урахування індивідуального рівня психофізичного розвитку, можуть здобувати валеологічні знання i без особливого перенавантаження та труднощів виконувати навчальні завдання [3]. При цьому необхідно формувати готовність майбутніх фахівців з ФВ у ДУ, 3 якими діти 3 великим бажанням i інтересом будуть включатися в педагогічний процес, а саме навчання стає методично наповненим, гнучким і позитивно емоційним [4, 5]. Такий підхід передбачає наявність ситуації вибору, що дозволяє всім учасникам навчально-виховного процесу аналізувати та оцінювати власні здібності і можливості, рівень індивідуальної валеологічної підготовленості, формувати свою особистісну неповторність [6].

\section{2. Постановка проблеми}

У зв'язку 3 вище сказаним особливого значення набуває необхідність в обгрунтуванні i розкритті сутнісних характеристик складових компонентів моделі диференційованого підходу до валеологічної діяльності та виховання дошкільнят.

\section{3. Огляд літератури}

У науковій та спеціальній літературі є багато відомостей про широке використання в педагогічній практиці методів проектування і моделювання [4, 6, 7]. Метод моделювання вважається одним з основних як теоретичних, так і експериментальних напрямків у пізнанні, на якому базуються сучасні наукові 
дослідження. На думку більшості вчених процес моделювання здійснюється, як організація, відтворення, теоретична імітація процесів i результатів діяльності людини шляхом штучного конструювання середовища цієї діяльності.

В деяких джерелах модель в широкому розумінні розглядається як специфічна форма спрощення дійсності, замінник і засіб оперування спрощеним образом об'єкта, що використовується як еталон, стандарт того чи іншого процесу або явища $[2,8]$.

У педагогіці модель як логічна схема виступає стосовно змістовної теоретичної області в якості способу інтерпретації та прогнозування результатів людської діяльності, для якої справедлива формула: "спостерігати - аналізувати - діяти - передбачати" $[6,9]$.

Як відзначає В. М. Сфимова [10], модель може виступати як засіб, так i форма пізнання для виявлення спільних i відмінних властивостей досліджуваних процесів, і як спосіб конкретизації та систематизації безпосередніх знань. Крім того, модель в ході розвитку знань виступає також специфічною формою абстракції і стає засобом матеріалізації образу запланованої педагогічної діяльності в рамках реалізації вищевикладеної формули поведінки [7].

В нашому розумінні вона реалізується в різних функціях: як своєрідна структура чи схема, зразок або засіб абстракції педагога “бачити передбачати - діяти”. При моделюванні валеологічної освіти дошкільнят і досягненні мети валеологічної діяльності майбутніх інструкторів з ФВ в системі сучасної дошкільної освіти необхідно встановити складові компоненти моделі диференційованого підходу (МДП).

4. Структура i теоретична база моделі диференційованого підходу до валеологічної освіти дошкільнят

МПД передбачає ряд компонентів: вихідний рівень психо-фізичного розвитку чи готовність дітей до школи, мета і зміст валеологічної освіти, навчання та його функції, педагогічну технологію диференційованого підходу до освіти дошкільнят, що включає діяльність інструктора 3 ФВ, його професійну готовність й діяльність дітей, відносини між якими встановлюються на основі навчальної взаємодії і стилів педагогічного спілкування.

При навчальній взаємодії інструктора з ФВ і дітей, побудованій на аксіологічному стилі педагогічного спілкування, створюються повноцінні психолого-педагогічні умови для розвитку мотивації валеологічної освіти, пізнавальної активності та особистісних якостей дошкільнят, що визначається в ході діагностики, заснованої як на виявленні показників готовності до вивчення здоров'я зберігаючих технологій, так і на критеріях розвитку у дошкільнят ряду педагогічних якостей: спостережливість, практична діяльність, працездатність, самооцінка, здатність до навчання, мислення.

"Початковий рівень розвитку i готовність дітей до школи" як компонент МДП визначається за рівнем розумового і вербального розвитку, здібностей дитини орієнтуватися в навколишньому середовищі, запасу індивідуальних знань, відношення до школи, рівня розвитку творчих уявлень, дрібної і великої моторики.

Основна функція другого компоненту МДП "мета валеологічної освіти" - полягає в управлінні, регулюванні і досягненні мети валеологічної діяльності інструктора з ФВ в ДУ $[7,11]$.

На думку М. В. Пазиркіна і співав. [12, 13], в такому вигляді мета виступає як системоутворюючий фактор. У нашій МДП валеологічної освіти цей компонент $\epsilon$ важливою складовою частиною всієї структури, яка мобілізує всю систему валеологічної освіти дошкільників.

Як доведено Г. І. Сопко і співав. [14, 15], в основі цілеспрямованої поведінки лежить “модель прогнозованого майбутнього”, яка власне, дозволяє виділити відповідний об'єкт та вирішувати проблеми пов'язані з цим. У педагогіці, цілі розглядаються як об'єкт освіти та інтегрують цілий ряд чинників, що визначають мотивацію і саморегуляцію діяльності людини [16].

У нашій теоретичній моделі диференційованого підходу до валеологічного утворенню мети інструктора 3 ФВ і дошкільнят розглядаються також, як феномени свідомості i реалізуються через механізми цільово навчання i цілепокладання, що формуються в процесі валеологічної діяльності в ДУ.

Такий компонент як “зміст валеологічної освіти”, усвідомлене інструктором з ФВ і процес його засвоєння повинні розглядатися, як найважливіші дії 3 реалізації мети і завдань валеологічної діяльності з урахуванням вимог часу. 3 цієї точки зору освіта $є$ суспільно організованим i педагогічно спрямованим процесом засвоєння дитиною соціального досвіду, внаслідок чого відбувається підготовка дитини до життя в суспільстві (соціалізація) і його особистісне формування і розвиток (індивідуалізація) $[11,17]$.

При цьому змістом освіти є система наукових знань, способів діяльності і соціальних відносин, якими повинні оволодіти діти в цьому процесі $[10,13]$.

Наступний компонент моделі - “навчання" повинен розглядатися, як процес стимуляції та управління активністю дошкільнят, в результаті якої у них формуються певні наукові знання, навички та вміння (освітня функція); як засіб формування навчальних, соціальних мотивів, ідеалів, наукового світогляду, звичок i норм поведінки дитини в суспільстві (виховна функція); як процес стимулювання та управління пізнавальною активністю, в результаті чого відбувається не тільки освоєння людського досвіду, а й формування психічних процесів і багатьох особистісних якостей $\mathrm{i}$ властивостей дітей (розвиваюча функція) $[15,16]$.

Важливим компонентом МДП до освіти дошкільнят $\epsilon$ "педагогічна технологія диференційованого підходу до освіти”. Поняття “технологія” 
означає сукупність знань, навичок i умінь, які дозволяють організувати і здійснити певні процеси [4, 6-10]. Під технологією в широкому сенсі цього слова слід розуміти конкретне, науково обгрунтоване і спеціальним чином організоване навчання.

Ми виходили з того, що “сучасні технологічні моделі навчання виражають основні методологічні принципи побудови навчання, методологію гуманістичного, розвивального, особистісноорієнтованого проекту організації навчання" [9, 13].

Проблема використання педагогічних технологій в освіті містить ще багато невивчених питань. Центральною серед них сьогодні $є$ питання про дефініції педагогічної технології. Кожен дослідник дає своє визначення цього поняття, розкриває його сутність відповідно до методології, на яку він опирається. Наприклад, А. М. Ващенко [7] вважає, що “педагогічна технологія $\epsilon$ областю дослідження теорії та практики, що має зв’язки 3 усіма сторонами організації педагогічної системи для досягнення специфічних і потенційно відтворюваних педагогічних результатів".

На думку Т. І. Бичкової [6], “технологія навчання це теоретичний проект педагогічного управління навчальною діяльністю i система необхідних коштів, що забезпечують функціонування педагогічної системи згідно заданим цілям освіти і розвитку дошкільників".

Ми поділяємо позицію I. А. Єрохіної [9] в тому, що будь-яка педагогічна технологія $\epsilon$ своєрідним проектом певної педагогічної системи, реалізованим на практиці. 3 урахуванням зазначеного можна припустити, що за допомогою технології навчання можливо реалізувати ту чи іншу теорію навчання, стратегію управління навчальною діяльністю, а також здійснити сукупність процедур, пов'язаних 3 управлінською діяльністю в системі освіти.

Педагогічна технологія розглядається нами як певна система способів, прийомів процедурного представлення педагогічного процесу, побудована на основі діяльнісного підходу і демократичного стилю педагогічного спілкування, врахування вікових, індивідуальних особливостей дошкільнят, застосування всіляких знаково-символічних засобів навчання та форм навчальної взаємодії дошкільнят, інструктора 3 ФВ і інших значущих дорослих, що дозволяють стимулювати пізнавальну активність, ініціативу, емоційно-потребуючу і когнітивну сферу особистості дошкільників з різним рівнем розвитку $\mathrm{i}$ підвищувати їх працездатність на основі формування мотивації навчання.

Педагогічна технологія диференційованого підходу до освіти дошкільнят, побудована на навчальній взаємодії та співробітництві інструктора 3 ФВ і дошкільнят, а також значимих для дитини “інших" дорослих (батьків, героїв літературних текстів тощо). Сприяє, перш за все, гуманізації процесу навчання, усвідомленню i засвоєнню навчального матеріалу учнями всіх рівнів розвитку, тобто навченості, формуванню особистісних якостей (спостережливість, самостійність, вмотивованість), що позитивно позначається на взаєминах між дітьми. Найбільш “слабкі" і “середні" за рівнем розвитку дошкільники почувають себе “захищеними” в колективі однолітків, що надає їм впевненості у прийнятті та вирішенні поставлених завдань.

Стиль педагогічного спілкування багато в чому визначає ефективність навчальної взаємодії інструктора 3 ФВ і дошкільнят при реалізації педагогічної технології валеологічної діяльності. Педагоги-дослідники виділяють авторитарний, поступальний, демократичний стилі педагогічного спілкування.

При авторитарному стилі спілкування інструктор з ФВ, як правило, одноосібно вирішує всі питання, що відносяться до сфери життєдіяльності всього колективу дошкільнят і кожного окремо.

Поступальний (анархічний, який ігнорує) стиль педагогічного спілкування характеризується прагненням педагога мінімально включатися в діяльність. Педагоги, що вдаються до даного стилю спілкування, виконують свої функціональні обов'язки формально.

Демократичний стиль спілкування $\epsilon$ альтернативою двом вищеназваним стилям. Його нерідко називають “стилем співпраці”. При демократичному стилі спілкування педагог постійно орієнтований на підвищення суб'єктивної ролі дітей у взаємодії, на навчальну взаємодію і співпрацю 3 учнями - представниками різних груп за рівнем розвитку, на гуманізацію процесу навчання. Демократичний стиль спілкування - ефективний спосіб організації процесу навчання та взаємодії інструктора з ФВ і дошкільнят.

Це позитивно позначається на формуванні у дошкільників мотивації до навчання. Поняття "мотивація" в психолого-педагогічній науці розглядається як спонукання, що викликають активність організму і визначає його спрямованість на щось. Це поняття співвідноситься 3 іншим поняттям - бажанням вчитися $[1,3,5]$.

Наступним компонентом моделі $\epsilon$ "професійна готовність" як пізнавальна спрямованість особистості інструктора з ФВ, що включає його загальногромадянські якості i властивості, які визначають значимість професії інструктора з ФВ, його спеціальні знання, навички та вміння, а також духовні потреби та інтереси, педагогічні здібності i структуру педагогічної діяльності.

Професійна готовність включає три найбільш важливих складових - психологічну, психофізіологічну i фізичну готовність. Крім того, вона містить науково-теоретичну і практичну підготовку як основу професіоналізму. Зміст професійної готовності відображає інваріантні, ідеалізовані параметри особистості та професійної діяльності інструктора з ФВ [3, 5, 17].

Не менш значимими компонентами розробленої нами моделі $€$ критерії, за якими виявлялася динаміка розвитку дошкільнят. В якості критеріїв було визначено: спостережливість як властивість і якість особистості; практична 
діяльність, як інтегративний показник, що характеризує прогресування дітей у розвитку, 3 одного боку, власне-рухових умінь і навичок, а 3 іншого - сенсорної сфери, просторових уявлень i розумової діяльності дошкільників; мислення як процес свідомого відображення дійсності в таких об'єктивних iï властивостях, зв'язках і відносинах, в які включаються i недоступні безпосередньому чуттєвому сприйняттю об'єкти; самооцінка, як компонент самосвідомості, тобто усвідомлення дошкільнятам самого себе, своїх фізичних сил, розумових здібностей, вчинків, мотивів і мети своєї поведінки, свого ставлення до навколишнього середовища, до інших людей і до самого себе, будучи стійким структурним утворенням, компонентом “Я-концепціiі”; працездатність як характеристика готовності або потенційних можливостей дошкільнят виконувати навчальну діяльність на заданому рівні ефективності протягом певного часу (дня, тижня, навчальної чверті, півріччя тощо); здатність до навчання як характеристика індивідуальних можливостей дошкільнят для засвоєння нових знань, дій і виконання навчальної діяльності.

\section{5. Висновок}

Розроблена нами теоретична модель диференційованого підходу до освіти дошкільнят виступає своєрідною структурною схемою, зразком i засобом матеріалізації запланованої валеологічної діяльності інструктора з ФВ в дошкільних закладах освіти. Вона спрямована на реалізацію мети початкової освіти і здійснюється через механізми мотивації i визначення мети, яка формується в педагогічній взаємодії інструктора з ФВ і дітьми дошкільного віку.

\section{Литература}

1. Бахтин, Ю. К. Факторы формирования здоровья человека и их значение [Текст] / Ю. К. Бахтин // Молодой ученый. - 2012. - № 5. - С. 397-400.

2. Бахтин, Ю. К. Формирование культуры здоровья ответственная задача учреждений народного образования [Текст] / Ю. К. Бахтин, Г. И. Сопко, М. В. Пазыркина // Молодой учёный. - 2012. - № 4. - С. 445-447.

3. Бирюкова, Ю.Н. Формирование здорового образа жизни у учащихся общеобразовательной школы на основе здоровьесберегающих технологий [Текст] : дис. ... канд. педаг. наук: 13.00.01 / Ю. Н. Бирюкова. - Краснодар, 2004. $-155 \mathrm{c}$

4. Божедомова, С. В. Формирование готовности студентов к использованию здоровьесберегающих технологий в профессиональной деятельности: на примере подготовка учителей начинающих классов [Текст] : дис. ... канд. педаг. наук: 13.00 .08 / С. В. Божедомова. - Тольятти, 2011. -265 c.

5. Брехман, И. И. За всенародное движение «Здоровый Мир» [Текст] / И. И. Брехман // Педагогические вести. - 1996. - № 9. - С. 3.

6. Бычкова, Т. И. Организация учебновоспитательного процесса в общеобразовательной школе на основе здоровьесберегающих технологий [Текст] : дис. ... канд. педаг. наук / Т. И. Бычкова. - Чебоксары, 2005. $-173 \mathrm{c}$.

7. Ващенко, А. М. Здоровьесберегающие технологии в общеобразовательных учебных заведениях
[Текст] / А. М. Ващенко, С. А. Свириденко // Директор школы (Школьный мир). - 2006. - № 20. - С. 13-14.

8. Виленская, Т. Е. Теория и технология здоровьесбережения в процессе физического воспитания детей младшего школьного возраста [Текст]: дис. .. д-р педаг. наук: 13.00 .04 / Т. Е. Виленская. - Краснодар, 2007. $-515 \mathrm{c}$.

9. Ерохина, И. А. Здоровьесберегающие технологии в профилактике наркозависимости подростков: диссертация кандидата педагогических наук [Текст] : 13.00.02 / И. А. Ерохина. - Тамбов, 2005. - 272 с.

10. Ефимова, В. М. Здоровьесберегающие технологии в контексте педагогических исследований [Текст] / В. М. Ефимова // Педагогика, психология и медико-биологические проблемы физического воспитания и спорта. - 2010. - № 1. - С. 57-60.

11. Зайцев, Г. К. Педагогика здоровья. Основы собриологии, валеологии, социальной педагогики и алкологии [Текст] / Г. К. Зайцев // Валеопедагогика. 2003. - Вып. 12. - С. 25-27.

12. Пазыркина, М. В. Значение формирования здоровьесберегающих компетенций педагога [Текст] / М. В. Пазыркина, Г. И. Сопко // Школа будущего. - 2013. № 2. - C. 138-142.

13. Пазыркина, М. В. Формирование здоровьесберегающей компетентности будущего педагога [Текст] : матер. междунар. конф. / М. В. Пазыркина, Г. И. Сопко // Безопасность жизнедеятельности: психологопедагогические и медико-биологические аспекты. Ярославль: Изд-во ЯГПУ, 2013. - С. 135-139.

14. Сопко, Г. И. Культура здоровья - важнейший компонент народного образования [Текст] / Г. И. Сопко, М. В. Пазыркина // Здоровьесберегающее образование. 2013. - Т. 29, № 1. - С. 88-93.

15. Сопко, Г. И. Основы формирования культуры здоровья в педагогическом образовании [Текст] / Г. И. Сопко, М. В. Пазыркина // Безопасность жизнедеятельности: психолого-педагогические и медикобиологические аспекты. - 2013. - С. 155-159.

16. Сыромятникова, Л. И. Формирование медиковалеологической компетентности будущих специалистов безопасности жизнедеятельности в педагогическом вузе [Текст]: автореф. дис. ... канд. педаг. наук. / Л. И. Сыромятникова. - АППО, 2009. - 20 с.

17. Чудак, В. В. Создание здоровьесберегающей образовательной среды для участников учебновоспитательного процесса [Текст] / В. В. Чудак // Основы здоровья и физическая культура. - 2007. - № 9. - С. 14-15.

\section{References}

1. Bahtin. Yu. K. (2012) Faktory farmyrovanya zdorovia cheloveka I ikh znanya [Formation factors on human health and their meaning]. Molodoi uchenyi 397-400.

2. Bahtin, Yu. K., Sopko, G. I., Pazyrkina, M. V. (2012) Formirovanie kultury zdorovia - otvetstvennaia zadacha uchrezhdeny narodnogo obrazovanija [Building a culture of health - an important task of public education institutions] Molodoj uchjonyj, 445-447.

3. Biriukova, Yu. N. (2004). Formirovanie zdorovogo obraza zhizni u uchashhihsja obshheobrazovatelnoi shkoly na osnove zdorov'esberegayushchikh tehnologi [Promoting a healthy lifestyle among students of secondary schools on the basis of health-technology] Krasnodar, 155.

4. Bozhedomova, S. V. (2011). Formirovanie gotovnosti studentov $\mathrm{k}$ ispol'zovaniu zdorov'esberegaiushhikh tehnologii $\mathrm{v}$ professional'noi deiatel'nosti [Formation of readiness of students to use technology in health-professional activities] Tol'jatti, 265.

5. Brehman, I. I. (1996) Za vsenarodnoe dvizhenie [For 
a popular movement] «Zdorovyj Mir» Pedagogicheskie vesti, 3. 6. Bychkova, T. I. (2005). Organizaciia uchebnovospitatel'nogo processa $\mathrm{v}$ obshheobrazovatel'noij shkole na osnove zdorov'esberegaiushhikh tehnologii [Organization of the educational process in a comprehensive school-based health-technology] Cheboksary, 173.

7. Vashhenko, A. M. (2006). Zdorov'esberegaiushchie tehnologii $\mathrm{v}$ obshheobrazovatel'nikh uchebnyh zavedeniiah [Health-technology in secondary schools] (Shkol'nyj mir), 20, $13-14$.

8. Vilenskaia, T. E. (2007) Teorija i tehnologiшa zdorov'esberezheniшa $\mathrm{v}$ processe fizicheskogo vospitaniшa detew mladshego shkol'nogo vozrasta [Theory and technology of health preservation in the physical education of children of primary school age] Krasnodar, 515.

9. Erohina, I. A. (2005) Zdorov'esberegaiushhie tehnologii $\mathrm{V}$ profilaktike narkozavisimosti podrostkov [Technologies will be in the prevention of adolescent drug] Tambov., 272.

10. Efimova, V. M. (2010). Zdorov'esberegaiushhie tehnologii $\mathrm{V}$ kontekste pedagogicheskih issledovanii [Technologies will be in the context of educational research] Pedagogika, psihologija i mediko-biologicheskie problemy fizicheskogo vospitanija i sporta, 1, 57-60.

11. Zaicev, G. K. (Ed.) (2003) Pedagogika zdorov'ia (Valeopedagogika) Osnovy sobriologii, valeologii, sotsialnoi pedagogiki i alkologii [Pedagogy of Health], 25-27.

12. Pazyrkina, M. V., Sopko, G. I. (2013). Znachenie

formirovaniia zdorov'esberegaiushhih kompetencii pedagoga [Of the development of health-teacher competences] Shkola budushhego, 2, 138-142.

13. Pazyrkina, M. V., Sopko, G. I. (2013).

Formirovanie zdorov'esberegaiushhei kompetentnosti budushhego pedagoga Bezopasnost zhiznedejatel'nosti [Formation of health-competence of future teachers] materialy mezhdunarodnoj konferencii Izd-vo JaGPU (Jaroslavl'), $135-139$.

14. Sopko, G. I., Pazyrkina, M. V. (2013). Kul'tura zdorovia - vazhneishii komponent narodnogo obrazovaniia [Culture of health - an essential component of public education], 1 (29), 88-93.

15. Sopko, G. I., Pazyrkina, M. V. (2013). Osnovy formirovaniia kul'tury zdorovia $\mathrm{v}$ pedagogicheskom [Basics of building a culture of health in teacher education] psihologopedagogicheskie i mediko-biologicheskie aspekty. Jaroslavl' Izd-vo JaGPU, 155-159.

16. Syromiatnikova, L. I. (2009) Formirovanie medikovaleologicheskoi kompetentnosti budushhikh specialistov bezopasnosti zhiznedeiatelnosti $\mathrm{v}$ pedagogicheskom vuze [Formation of health valeologicheskoj competence of the future life safety specialists in pedagogical high school], 20.

17. Chudak, V. V. (2007). Sozdanie zdorov'esberegaiushhei obrazovatel'noi sredy dlja uchastnikov uchebno-vospitatel'nogo [Creating health-educational environment for the participants of the educational process] Osnovy zdorov'ja i fizicheskaja kul'tura, 9, 14-15.

Рекомендовано до публікаиії д-р педаг. наук Завгородня Т. С. Дата надходження рукопису 15.10.2014

Семанишин Тарас Михайлович, аспірант, кафедри теорії та методики фізичної культури і спорту, Прикарпатський національний університет ім. В. Стефаника, вул. Шевченка, 57, м. Івано-Франківськ, 76025, Україна

Презлята Ганна Василівна, кандидат педагогічних наук, доцент, кафедри теорії та методики фізичної культури і спорту, Прикарпатський національний університет ім. В. Стефаника, вул. Шевченка, 57, м. Івано-Франківськ, 76025, Україна

Попель Сергій Любомирович, доцент, кафедра теорії та методики фізичної культури і спорту, Прикарпатський національний університет ім. В. Стефаника, вул. Шевченка, 57, м. Івано-Франківськ, 76025, Україна

E-mail: serg_popel@mail.ru

УДК 378.011.3-051: 373.3

DOI: $10.15587 / 2313-8416.2014 .28821$

\section{ПІДГОТОВКА МАЙБУТНІХ УЧИТЕЛІВ ДО СУБ'ЄКТ-СУБ'ЄКТНОЇ ВЗАЄМОДІї З УЧНЯМИ}

(C) О. О. Ліннік

У статті представлено теоретичне обтрунтування системи підготовки майбутнього вчителя до суб'єкт-суб'єктної взаємодії з учнями. Система базується на принцииах: гуманізації освітньопрофесійного середовища, свободи вибору траєкторії розвитку, взаємозв'язку сфер діяльності, культуровідповідності, иціннісного ставлення до співпраці, співробітництвва суб'єктів у всіх сферах діяльності. Процес підготовки вчителів складається з чотирьох етапів.

Ключові слова: суб'єкт, взаємодія, середовище, майбутній учитель, система підготовки, гуманізачія, навчальні смисли.

This article describes a theoretical grounding for prospective teacher training system to subject-subjective interaction with pupils. The system is based on the next principles: humanization of education and professional environment, free trajectory evolution choice, relationship of fields of activity, cultural correspondence, value attitude to collaboration and cooperation of subjects in all fields of activity. The process of teacher training consists of four stages.

Keywords: subject, interaction, environment, prospective teachers, training system, humanization, training meanings. 